\title{
A CURSORY APPLICATION OF DRASTIC TO THE SAVANNAH RIVER SITE *
}

By

S. S. Crider

Division of Engineering Fundamentals

Virginia Polytechnic Institute and State University

Blacksburg, Virginia 24061-0218

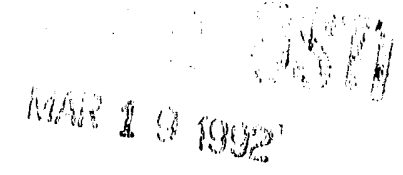

\section{DISCLAIMER}

\begin{abstract}
This report was prepared as an account of work sponsored by an agency of the United States Government. Neither the United States Government nor any agency thereof, nor any of their employees, makes any warranty, express or implied, or assumes any legal liability or responsibility for the accuracy, completeness, or usefulness of any information, apparatus, product, or process disclosed, or represents that its use would not infringe privately owned rights. Reference herein to any specific commercial product, process, or service by trade name, trademark, manufacturer, or otherwise does not necessarily constitute or imply its endorsement, recommendation, or favoring by the United States Government or any agency thereof. The views and opinions of authors expressed herein do not necessarily state or reflect those of the United States Government or any agency thereof.
\end{abstract}

\footnotetext{
*This paper was prepared in connection with work done under Contract No. DE-AC0976SR00001 (now Contract No. DE-AC.09-88SR18035) with the U.S. Department of Energy. By acceptance of this paper, the publisher and/or recipient acknowledges the U.S. Government's right to retain a nonexclusive, royalty-free license in and to any copyright covering this paper, along with the right to reproduce and to authorize others to reproduce all or part of the copyrighted paper.
} 
SRS

A CURSORY APPLICATION OF DRASTIC TO THE SAVANATAH RIVER SITE (8RS)

S. S. Crider

Division of Engineering Fundamentals

Virginia Polytechnic Institute and State University

Room 332 Randolph Hall

Blacksburg, Virginia 24061-0218 
Factors Considered

DRASTIC Applied to the SRS

Sitewide Factors

Depth to the Water Table

Soil Media

Topography 
1 Sources of Hydrologic Information 4

2 Assigned Weights for DRASTIC Factors 5

3 Ranges and Ratings for Depth to water Table 5

4 Ranges and Ratings for Net Recharge 5

5 Ranges and Ratings for Aquifer Media 5

6 Ranges and Ratings for Soil Media 6

7 Ranges and Ratings for Topography 6

8 Ranges and Ratings for Impact of Vadose Zone 6

9 Ranges and Ratings for Hydraulic conductivity 6

10 Sitewide Factors at SRS 10 


\section{LIST OF FIGURES}

Figure

Page

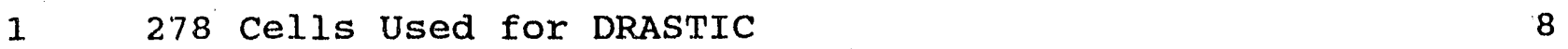

2 Depth to the Water Table Ratings 11

3 Location of Soil Survey Sheets 12

4 Soil Media Ratings 13

5 Topography Ratings : 15

6 Overall DRASTIC Indices for Each Cell 17

7 Color-coded DRASTIC Index Map $\quad 18$ 
Geohydrologists at the National Water Well Association (NWWA) created DRASTIC as a formalized decision-making procedure to assess the potential for groundwater pollution at existing and proposed industrial sites. It is a straightforward, step-by-step method to size up, with existing information, groundwater pollution potential anywhere in the country. DRASTIC is generalized because it is meant to be universal; therefore, NWWA stresses its qualitative nature. Its objectives are: (1) to help direct resources and land use activities to appropriate areas; and, (2) to help prioritize groundwater protection, monitoring and cleanup efforts.

Even though it is a general siting tool, usually applied where only scanty geohydrological information is available, it can be helpful-perhaps in a modified form--for locations like the sRs that have relatively abundant data resources. Consequently, my intention here is to demonstrate its use at the SRS, in a very cursory fashion, only to show how it might be useful if applied in a more rigorous way.

\title{
FACTORS CONSIDERED
}

DRASTIC is an acronym formed from the 7 factors it considers for any hydrogeologic setting:

\author{
Depth to the water table, \\ net Recharge, \\ Aquifer media,
}



Soil type,
Topography,
Impact of the vadose zone, and,
hydraulic conductivity.

Applying DRASTIC amounts to finding information on each factor (e.g., from sources listed in Table 1) in order to assign ratings (numbers from 1 to 10) to each factor, then taking weighted sums of these ratings to get DRASTIC indices, which are comparative measures of pollution potential. Since a rating of 1 represents lowest pollution potential (more favorable siting) and 10 highest (less favorable siting), the lower the DRASTIC index the more suitable the site would be for an industrial or waste site location. Weights vary from 1 for the least influential factor to 5 for the most. Thus, according to Table 2, depth to the water table has more effect on groundwater pollution potential than topography. Table 2 also shows that DRASTIC assigns different weights to the factors if the land under study is primarily agrıcultural, in which case pollution generally originates from non-point sources. Tables 3 through 9 display the ratings for each factor.

The equation for the DRASTIC index is:

$$
\begin{aligned}
\text { DRASTIC INDEX }=D_{R} D_{W} & +R_{R} R_{W}+A_{R} A_{W}+S_{R} S_{W}+T_{R} T_{W} \\
& +I_{R} I_{W}+C_{R} C_{W} \ldots \ldots \ldots
\end{aligned}
$$


where $\mathrm{R}$ is the rating and $\mathrm{W}$ the weight. Again, low DRASTIC indices imply relatively more favorable sites than high indices.

\section{LIMITATIONS}

Clearly DRASTIC is bare-bones, ignoring factors like the aquifer value; i.e., population served or proximity to cities and towns. It also deals only with water table aquifers, ignoring geologic features which affect groundwater pollution like aquitards overlying deeper aquifers, or anomalous preferential flow paths. DRASTIC pays little attention to land use, and none at all to political considerations. It includes no provisions for seismic activity. In effect, it integrates and smooths out spotty information and provjdes first approximations. "It assumes the following:

- pollutant sources at ground surface,

- miscible pollutants flushed into the groundwater by precipitation, and,

- that it applies to areas 100 acres or larger. 
Table 1. Sources of Hydrologic Information

\begin{tabular}{|c|c|c|c|c|c|c|c|}
\hline source & $\begin{array}{l}\text { Depth } \\
\text { to } \\
\text { Water } \\
\text { Table }\end{array}$ & $\begin{array}{l}\text { Net } \\
\text { Recharge }\end{array}$ & $\begin{array}{l}\text { Aquifer } \\
\text { Media }\end{array}$ & $\begin{array}{l}\text { Soil } \\
\text { Media }\end{array}$ & $\begin{array}{l}\text { Topo- } \\
\text { graphy }\end{array}$ & $\begin{array}{l}\text { Impact } \\
\text { of the } \\
\text { Vadose } \\
\text { Zone }\end{array}$ & $\begin{array}{l}\text { Hydr. } \\
\text { Cond. } \\
\text { of the } \\
\text { Aquifer }\end{array}$ \\
\hline State \& USGS & $\mathrm{X}$ & $\mathrm{x}$ & $\mathrm{X}$ & . & $\mathrm{X}$ & $\mathrm{X}$ & $\mathrm{X}$ \\
\hline $\begin{array}{l}\text { state Dept. of } \\
\text { Nat./Wat. Res. }\end{array}$ & $\mathrm{X}$ & $\mathrm{X}$ & $\mathrm{X}$ & & & $\mathrm{x}$ & $\mathrm{x}$ \\
\hline USDA-SCS & & $\mathrm{X}$ & & $\mathrm{X}$ & $\mathrm{X}$ & & \\
\hline State EPA & $\mathrm{X}$ & $\mathrm{X}$ & $\mathrm{X}$ & & & $\mathrm{X}$ & $\mathrm{X}$ \\
\hline $\begin{array}{l}\text { Clean water Act } \\
\text { "208" \& other } \\
\text { Regional Plan- } \\
\text { ning Auth.'s }\end{array}$ & $\mathrm{X}$ & $\mathrm{X}$ & $\mathrm{X}$ & & & $\mathrm{X}$ & $\mathrm{X}$ \\
\hline $\begin{array}{l}\text { County \& Regiona } \\
\text { Water Supply } \\
\text { Agencies \& }\end{array}$ & & & & $\cdots$ & & & \\
\hline Comp.'s & $\mathrm{X}$ & & $\mathrm{X}$ & & & $\mathrm{X}$ & $\mathrm{x}$ \\
\hline $\begin{array}{l}\text { Consultants } \\
\text { (hydrogeologic, } \\
\text { engineering) }\end{array}$ & $\mathrm{X}$ & & $\mathrm{X}$ & & & $\mathrm{X}$ & $\mathrm{X}$ \\
\hline $\begin{array}{l}\text { Related Ind. } \\
\text { studies (mining } \\
\text { well drilling, } \\
\text { quarrying) }\end{array}$ & g, & & $\mathrm{X}$ & - & & $\mathrm{X}$ & \\
\hline $\begin{array}{l}\text { Prof. Societies } \\
\text { (GSA, NWWA, AGU } \\
\text { ASCE) }\end{array}$ & U, & $\mathrm{X}$ & $\mathrm{X}$ & & & $\mathrm{x}$ & $\mathrm{x}$ \\
\hline $\begin{array}{l}\text { Local Coll.'s \& } \\
\text { Univ.'s (Dept.' } \\
\text { of Geology' Ear } \\
\text { Science, Civil } \\
\text { Engineering) }\end{array}$ & $\begin{array}{l}\text { 's } \\
\text { rth } \\
\\
\\
x\end{array}$ & $x$ & $\mathrm{X}$ & & & $\mathrm{X}$ & $\mathrm{X}$ \\
\hline \multicolumn{8}{|c|}{$\begin{array}{l}\text { Other Fed. \& State } \\
\text { Agencies (Army }\end{array}$} \\
\hline SRS Reports & $\mathrm{X}$ & $\mathrm{X}$ & $\mathrm{X}$ & $\mathrm{X}$ & $\mathrm{X}$ & $\mathrm{x}$ & $\mathrm{X}$ \\
\hline
\end{tabular}


Table 2. Assigned Weights for DRAsTIC Factors

\begin{tabular}{lcc}
\hline \multicolumn{1}{c}{ Factor } & Weight & $\begin{array}{c}\text { Agricultural } \\
\text { Weight }\end{array}$ \\
\hline Depth to the water Table & 5 & 5 \\
Net Recharge & 4 & 4 \\
Aquifer Media & 3 & 3 \\
Soil Media & 2 & 5 \\
Topography & 1 & 3 \\
Impact of the Vadose Zone & 5 & 4 \\
Hydraulic Conductivity of the Aquifer & 3 & 2 \\
\hline
\end{tabular}

Table 3. Ranges and Ratings for Depth to Water Table

Depth in feet

\begin{tabular}{cc}
\hline Range & Rating \\
\hline $0-5$ & 10 \\
$5-10$ & 9 \\
$15-30$ & 7 \\
$30-50$ & 5 \\
$50-75$ & 3 \\
$75-100$ & 2 \\
$100+$ & 1 \\
\hline
\end{tabular}

Table 4. Ranges and Ratings for Net Recharge

Recharge in inches/year

\begin{tabular}{cc}
\hline Range & Rating \\
\hline $0-2$ & 1 \\
$2-4$ & 3 \\
$4-7$ & 6 \\
$7-10$ & 8 \\
$10+$ & 9 \\
\hline
\end{tabular}

Table 5. Ranges and Ratings for Aquifer Media

\begin{tabular}{llc}
\hline \multicolumn{1}{c}{ Range } & Rating & Typical Rating \\
\hline Massive Shale & $1-3$ & 2 \\
Metamorphic/Igneous & $2-5$ & 3 \\
Weathered Metamorphic/Igneous & $3-5$ & 4 \\
Thin Bedded Sandstone, & $5-9$ & 6 \\
$\quad$ Limestone, Shale Sequences & $4-9$ & 6 \\
Massive Sandstone & $4-9$ & 6 \\
Massive Limestone & $6-9$ & 8 \\
Sand and Gravel & $2-10$ & 9 \\
Basalt & $9-10$ & 10 \\
Karst Limestone & & \\
\hline
\end{tabular}


Table 6. Ranges and Ratings for Soil Media

\begin{tabular}{lc}
\hline \hline Range & Rating \\
\hline Thin or Absent & 10 \\
Gravel & 10 \\
Sand & 9 \\
Shrinking and/or & 7 \\
Aggregated Clay & 6 \\
Sandy Loam & 5 \\
Loam Loam & 4 \\
Silty Loam Loam & 3 \\
Nlay-shrinking and Non- \\
aggregated Clay & 1 \\
\hline
\end{tabular}

Table 8. Ranges and Ratings for Impact of Vadose zone

\begin{tabular}{lcc}
\hline \multicolumn{1}{c}{ Range } & Rating & $\begin{array}{r}\text { Typical } \\
\text { Rating }\end{array}$ \\
\hline Silt/Clay & $1-2$ & 1 \\
Shale & $2-5$ & 3 \\
Limestone & $2-7$ & 6 \\
Sandstone & $4-8$ & 6 \\
Bedded Limestone, & & \\
$\quad$ Sandstone, Shale & $4-8$ & 6 \\
Sand and Gravel w/ & & \\
$\quad$ significant Silt & $4-8$ & 6 \\
and Clay & $2-8$ & 4 \\
Metamorphic/Igneous & $6-9$ & 8 \\
Sand and Gravel & $2-10$ & 9 \\
Basalt & $8-10$ & 10 \\
Karst Limestone & & \\
\hline
\end{tabular}

Table 7. Ranges and Ratings for Topography percent slope

\begin{tabular}{cc}
\hline Range & Rating \\
\hline $0-2$ & 10 \\
$2-6$ & 9 \\
$6-12$ & 5 \\
$12-18$ & 3 \\
$18+$ & 1 \\
\hline
\end{tabular}

\section{Table 9. Ranges and Ratings for Hydraulic conductivity}

Hydr. Cond. in gpd/ft $\mathrm{ft}^{2}$

\begin{tabular}{cc}
\hline Range & Rating \\
\hline $1-100$ & 1 \\
$100-300$ & 2 \\
$300-700$ & 4 \\
$700-1000$ & 6 \\
$1000-2000$ & 8 \\
$2000+$ & 10 \\
\hline
\end{tabular}


The creators of DRASTIC designed it for use at places where, unlike the SRS, geohydrologic data are sparse; nonetheless, applying it here yields at least two benefits:

- It reveals how a widely-accepted planning tool for groundwater protection measures relative pollution potential of existing industrial sites and the one chosen for the New Production Reactor (NPR) ; and,

- It hints at how DRASTIC might be tailored to include more accurate site-specific factors, or more thorough definition of factors to produce a more useful appraisal tool for the SRS.

Accordingly, I have applied DRASTIC to the SRS by way of an introduction to the DRASTIC method. The following paragraphs describe this application.

I began by dividing the site into 278 square cells roughly $1.7 \mathrm{~km} \mathrm{x}$ $1.7 \mathrm{~km}$ (because the map scale used was $1 . \mathrm{cm}=1 \mathrm{~km}$ ), as shown in Fig. 1 . The goal was to determine a DRASTIC index for each cell, then draw a color-coded DRASTIC index map of the SRS. The references used in addition to those listed at the end of this report were a topographic map of SRS, and, soil survey atlas sheets covering SRS (dated 10/13/87). The land on the SRS was. assumed to be non-agricultural. 


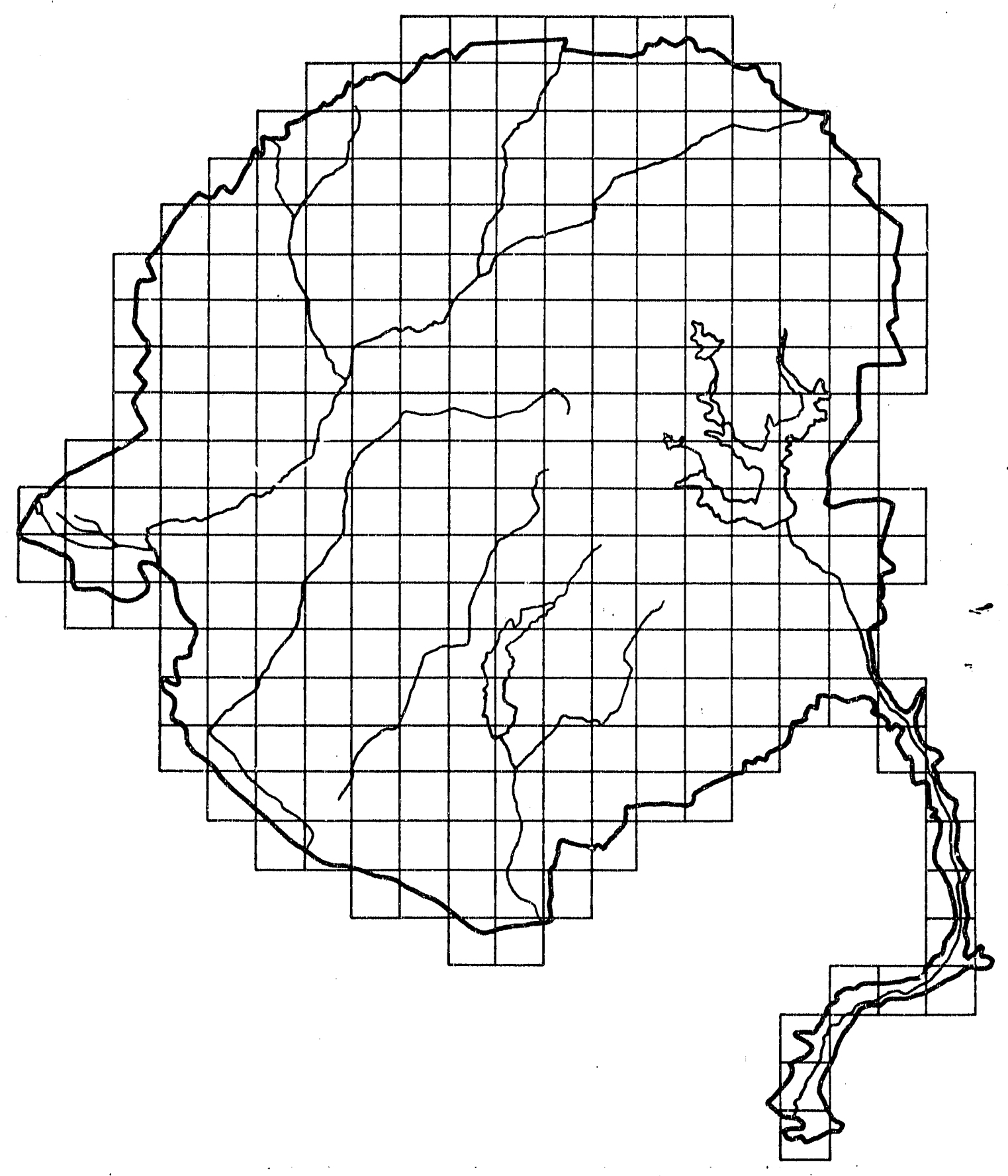

FIGURE 1. 278 Cells Used for DRASTIC 


\section{SITEWIDE FACTORS}

As shown in Table 10, 4 of the DRASTIC factors, net recharge, aquifer media, impact of the vadose zone, and hydraulic conductivity, received sitewide values. The reason is that there is no convenient documentation containing data on these 4 factors spread uniformly over the entire SRS; for instance, data on hydraulic conductivity mostly come from pump tests done in F, H and $\mathrm{M}$ areas. Likewise, Christensen and Gordon (1983) and Andersen et al. (1988) report net recharge at $15 \mathrm{in} / \mathrm{yr}$ across the site, even though it surely varies over hills and plains, forests and parking lots. Moreover, as Tables 4, 5, 8 and 9 show, one must select DRASTIC ratings for these factors from broad categories. I chose "Sand and Gravel" as the aquifer media, for example, because it characterizes the SRS water table aquifers better than any of the other choices.

On the other hand, there is probably sufficient data available somewhere on-site for each of thesf. 4 factors to make a much better estimate of their values. Applying DRASTIC could be seen, if for nothing else, as an impetus for consolidating and improving sitewide geohydrologic information.

The remaining 3 factors can best be covered individually.

\section{DEPTH TO THE WATER TABLE}

Using the topographic map with the sitewide map of the water table surface prepared by Andersen et al. (1988, Fig. 2.23), I obtained rough estimates of depth to the water table for all 278 cells. With the help of Table 4, I converted these depths to ratings, which are shown in Fig. 2 . 
Table 10. sitewide Factors at sRs

\begin{tabular}{|c|c|c|c|c|}
\hline Factor & $\begin{array}{l}\text { Characteristic } \\
\text { Value }\end{array}$ & Rating & Weight & $\begin{array}{l}\text { Factor } \\
\text { Index }\end{array}$ \\
\hline Net Recharge & $15 \mathrm{in} / \mathrm{yr}$ & 9 & 4 & 36 \\
\hline Aqquifer Media & Sand and Gravel. & 8 & 3 & 24 \\
\hline $\begin{array}{l}\text { Impact of the } \\
\text { Vadose Zone }\end{array}$ & $\begin{array}{l}\text { Sand and Gravel with } \\
\text { significant silt and clay }\end{array}$ & 6 & 6 & 36 \\
\hline $\begin{array}{l}\text { Hydraulic } \\
\text { Conductivity }\end{array}$ & $1.0-7.5 \mathrm{gpd} / \mathrm{ft}^{2}$ & 1 & 3 & 3 \\
\hline
\end{tabular}

\section{SOIL MEDIA}

I gathered data for soil media and topography from the soil survey atlas sheets. Fig. 3 shows the location of the 45 sheets superimposed on top of the grid. I selected the predominant soil types, up to 4 per cell, then used Table 7 to determine ratings for each cell. This led to the soil Media ratings shown in Fig. 4. The ratings for cells with several soil types are averages of those ratings. For example, suppose a cell's predominant soil types were Troup sand and Fuquay loamy sand, then the rating for that cell would be 8 :

$$
\frac{9(\text { for Troup sand) }+6 \text { (Fuquay loamy sand) }}{2}=7.5 \approx 8 .
$$

\section{TOPOGRAPHY}

The soil survey atlas sheets give not only soil types but also slopes or ranges of slopes, which made them useful for rating the site 


\begin{tabular}{|c|c|c|c|c|c|c|c|c|c|c|c|c|c|c|c|c|c|c|c|}
\hline & & & & & & & & & so & 3 & 75 & 1 & 21 & & & & & & \\
\hline & & & & & & لمر & & 3 & 5 & $7)$ & 5 & 1 & 2 & 2 & & & & & \\
\hline & & & & & $\sqrt{5}$ & 3 & 3 & 3 & 5 & 2 & 2 & 1 & 5 & 5 & 5 & & & & \\
\hline & & & & 4 & 1 & 2 & 3 & 2 & 5 & $\int 2$ & 5 & 5 & 5 & 3 & 2 & 2 & & & \\
\hline & & $7 / 3$ & & 1 & 2 & 2 & 2 & 3 & 10 & 5 & 5 & 2 & 1 & 3 & 2 & 2 & 3 & $\beta$ & \\
\hline & 10 & 2 & & 1 & 3 & 3 & 5 & 3 & 18 & 1 & 1 & 1 & 5 & 5 & 5 & 2 & 3 & $\beta$ & \\
\hline & 16 & 1 & & 3 & 3 & 9 & 10 & to & 1 & 1 & 1 & 2 & 5 & $2 \sqrt{25}$ & 5 & 7 & 7 & $\sqrt{5}$ & \\
\hline & 16 & 10 & & 10 & 5 & 5 & 1 & 2 & 2 & 5 & 5 & 5 & 5 & तु) & 5 & 53 & 3 & 7 & \\
\hline & 11 & 1 & & 10 & 5 & 10 & 5 & $\sqrt{5}$ & 5 & 7 & 5 & 5 & 5 & 12 & 7) & $\left\{\theta^{5}\right.$ & 8 & & \\
\hline 70 & 10 & 10 & & 10 & 10 & 5 & 3 & 3 & 3 & 5 & 7 & 7 & 76 & 2 & 70 & 5 & & & \\
\hline 1010 & 10 & 7 & & 10 & 3 & 7 & 3 & 3 & 3 & (9) & 5 & 2 & 3 & 10 & tot & 10 & 9 & 9 & \\
\hline$1 0 \longdiv { 1 0 }$ & 19 & 10 & & 3 & 1 & 5 & 3 & 3 & 3 & 3 & $3 /$ & 3 & 9 & 5 & 7 & 10 & 7 & 57 & \\
\hline 10 & 70 & 15 & & 7 & 7 & 3 & 3 & 3 & $\$$ & 35 & 37 & 3 & 7 & 7 & 7 & 7 & 108 & & \\
\hline & & $y$ & & 7 & 77 & 3 & 3 & 5 & $5\}$ & 8 & 5 & 54 & 5 & 5 & 5 & 7 & 10 & & \\
\hline & & $\xi$ & & 10 & 10 & 5 & 5 & 7 & 3 & 8 & 5 & 5 & 5 & 5 & 2 & $3^{5}$ & 108 & -1 & \\
\hline & & & & & 10 & 10 & 110 & 10 & 10 & 70 & 5 & 5 & 2 & 2 & דרקמ & & & & 8 \\
\hline & & & & 12 & $2 \theta$ & 10 & 10 & 10 & 10 & 10 & 5 & 5 & 2 & ${ }_{2}$ & & & & & 3) \\
\hline & & & & & 10 & 40 & 10 & 10 & 10 & 10 & $\sqrt{0}$ & & & & & & & & 16 \\
\hline & & & & & & & & & & 10 & 50 & & & & & & & & 1) \\
\hline & & & & & & & & & 10 & 10 & & & & & & & & & so \\
\hline & & & & & & & & & & & & & & & & & & & 10 \\
\hline & & & & & & & & & & & & & & & & & & & \\
\hline & & & & & & & & & & & & & & & & & & & \\
\hline & & & & & & & & & & & & & & & & भण & & & \\
\hline
\end{tabular}

FIGURE 2. Depth to the Water Table Ratings 


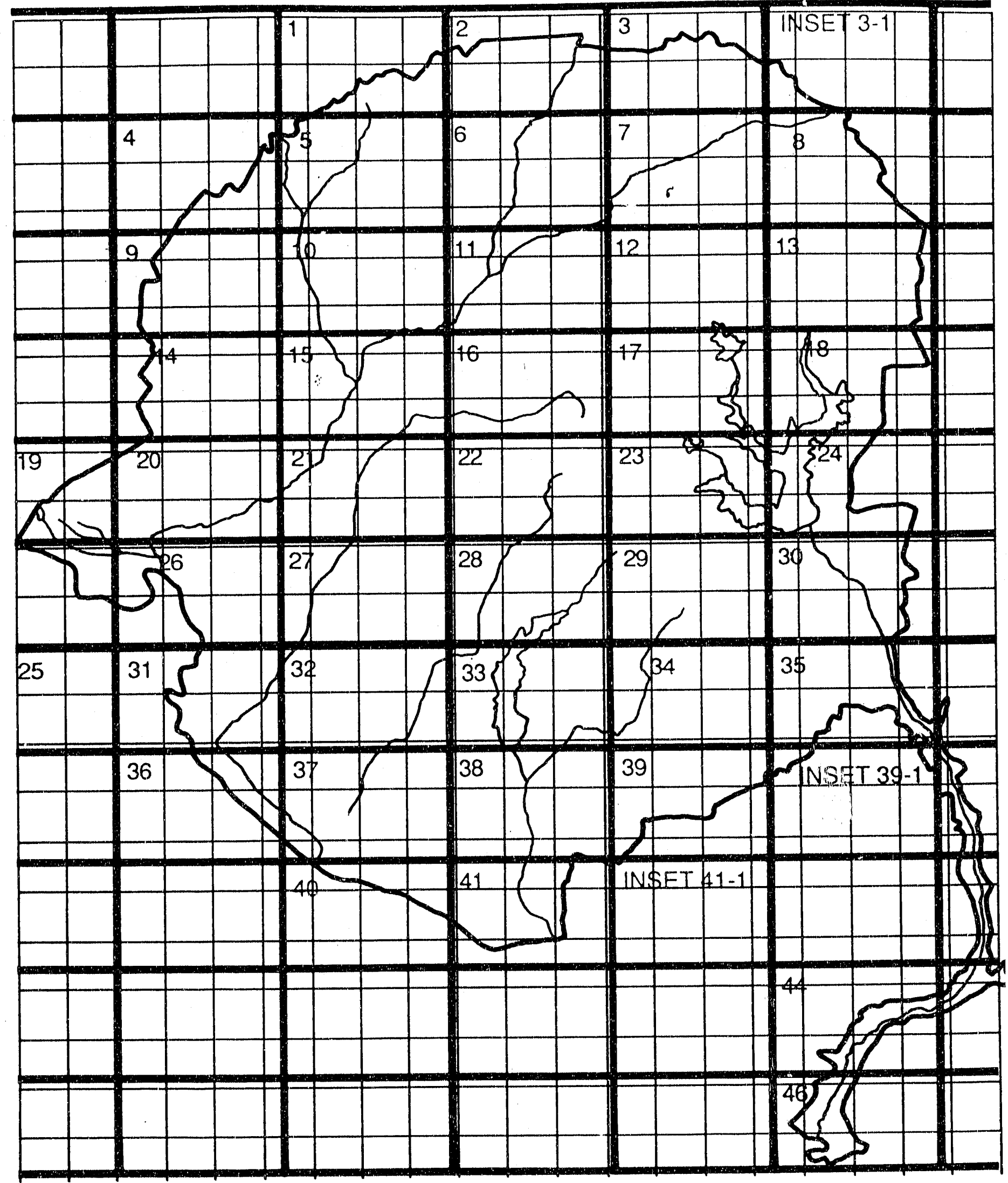

FIGURE 3. Location of Soil survey sheets 


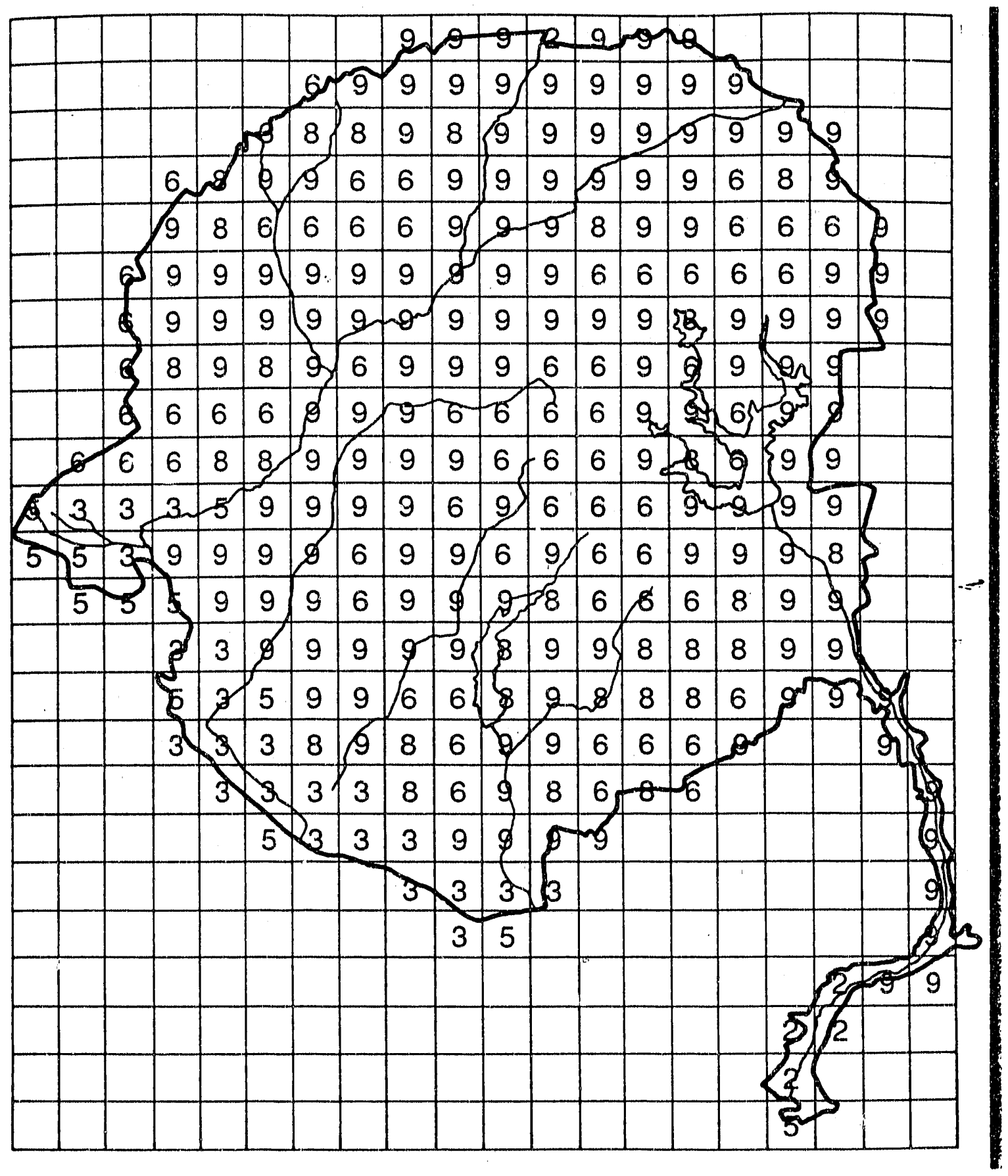

FIGURE 4. Soil Media Ratings 
topography since DRASTIC rates topography in terms of slopes. Slopes described as "frequently flooded," ranked as zero slopes; where they were given as ranges, e.g., $0 \%$ to $6 \%$, they were averaged (in this case, $3 \%$ ). Similarly, I computed mean values in cells where slopes varied considerably, like those near Upper Three Runs creek. I converted mean slopes to topography ratings using Table 7; these appear in Fig. 5 . 


\begin{tabular}{|c|c|c|c|c|c|c|c|c|c|c|c|c|c|c|c|c|c|c|c|}
\hline & & & & & & & & & Q & T & 70 & 10 & وتوم & & & & & & \\
\hline & & & & & & مور & 5 & 79 & 9 & 9 & 9 & 9 & 9 & 9 & 94 & & & & \\
\hline & & & & & 15 & 3 & 9 & 9 & 9 & 16 & 9 & 9 & 10 & T & 3 & 9 & 9 & & \\
\hline & & & & $d$ & $\$$ & 5 & 9 & 9 & 9 & 3 & 9 & $\sqrt{3}$ & 3 & 9 & 9 & 9 & $\$$ & & \\
\hline & & 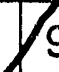 & & 10 & 9 & 9 & 9 & 9 & 19 & 10 & -3 & 9 & 9 & 5 & 9 & 9 & 9 & 8 & \\
\hline & $1 p$ & $\varsigma$ & 9 & 9 & 9 & 9 & 9 & 9 & 3 & 3 & 9 & 9 & 9 & 9 & 9 & 9 & 9 & $\beta$ & \\
\hline & 16 & 1 & 0 & 5 & 9 & 40 & 10 & -5 & 1 & 9 & 5 & 9 & 9 & 29 & 9 & 9 & 9 & 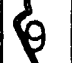 & \\
\hline & 16 & 1 & 0 & 9 & 9 & 10 & 9 & 9 & 9 & 9 & 9 & 9 & 9 & 9) & 9 & & q & 9 & \\
\hline & 18 & 1 & 0 & 10 & 9 & 10 & 5 & 9 & 5 & 9 & $\oint$ & 9 & $g$ & 3. & 99 & 20 & 8 & & \\
\hline 10 & 10 & 1 & 0 & 9 & 5 & 9 & 9 & 9 & 9 & 9 & 9 & 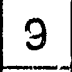 & 9. & 3 & 70 & $\{9$ & & & \\
\hline 1019 & 10 & 7 & of & to & 9 & 9 & 5 & 5 & 9 & 5 & 9 & 9 & 9 & ל. & 10 & 29 & 9 & 2 & \\
\hline$1 0 \longdiv { 1 0 }$ & 16 & 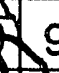 & & 9 & 9 & 5 & 9 & 9 & 5) & 9 & 5 & 9 & 9 & 9 & 9 & 10 & 5 & 8 & \\
\hline 10 & 70 & 1 & 8 & 9 & 9 & 9 & 9 & 9 & $\$$ & 9 & 39 & 9 & $\theta$ & 9 & 9 & 9 & 10 & 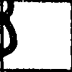 & \\
\hline & & 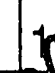 & $b$ & 10 & 10 & 9 & 10 & 5 & 9 & $\theta$ & 9 & $9\}$ & 9 & 5 & 9 & 9 & 10 & & \\
\hline & & 3 & 0 & 10 & 10 & 9 & 9 & 10 & 9 & 9 & 8 & o & 9 & 9 & 9 & $g^{d}$ & & 4 & \\
\hline & & 1 & $\alpha$ & & 10 & 10 & 10 & 9 & 10 & 8 & 9 & 9 & 9 & 9 & مكي & & & & $\mathbb{R}$ \\
\hline & & & & 12 & TQ & 10 & 10 & 10 & 9 & 10 & 9 & 19 & -9 & $\sqrt{9}$ & & & & & 48 \\
\hline & & & & & $10^{\circ}$ & 40 & 10 & 10 & 10 & 10 & 9 & 6 & & & & & & & (1) \\
\hline & & & & & & & & 10 & 10 & 10 & 110 & & & & & & & & 16 \\
\hline & & & & & & & & & 10 & 10 & & & & & & & & & $\therefore 0$ \\
\hline & & & & & & & & & & & & & & & & & & & 10 \\
\hline & & & & & & & & & & & & & & & & & 110 & & \\
\hline & & & & & & & & & & & & & & & & 16 & & & \\
\hline & & & & & & & & & & & & & & & & 40 & & & \\
\hline
\end{tabular}

FIGURE 5. Topography Ratings 


\section{RESULTS}

once I accumulated ratings for all. 7 factors in each of the 278 cells, I recorded them on a spreadsheet and calculated the DRASTIC index for every cell. These results appear in Fig. 6. Finally, Fig. 7 displays the end product, a color-coded DRASTIC index map.

Overall, the SRS appears moderately vulnerable to groundwatex pollution relative to other places of comparable size. About a third of it $(36 \%)$ is in the moderately vulnerable range of $160-179$; the rest is in the less vulnerable range below 159. The lowest (best) indices occur at the tops of hills or ridges because that is where the most telling factor, depth to the water table, is the most favorable. The highest (worst) indices appear where the water table is close to the ground surface, as along the Savannah River.

Had I used smaller cells, or differentiated, by cell, more than 3 of 7 factors, there would be finer detail; i.e., there would be more than 3 colors in Fig. 7. For example, Beard and Rowland (1988) applied DRASTIC to an $800 \mathrm{mi}^{2}$ county and produced an index map with 6 different color ranges. They used $30 \mathrm{~m} \times 30 \mathrm{~m}$ (instead of $1700 \mathrm{~m} \times 1700 \mathrm{~m}$ ) cells, and had available digital data bases for all 7 factors incorporated on geographical information system (GIS) software. Theirs was a much more thorough application of DRASTIC than the one reported here.

Fig. 7 shows that DRASTIC identifies the reference site for the NPR 


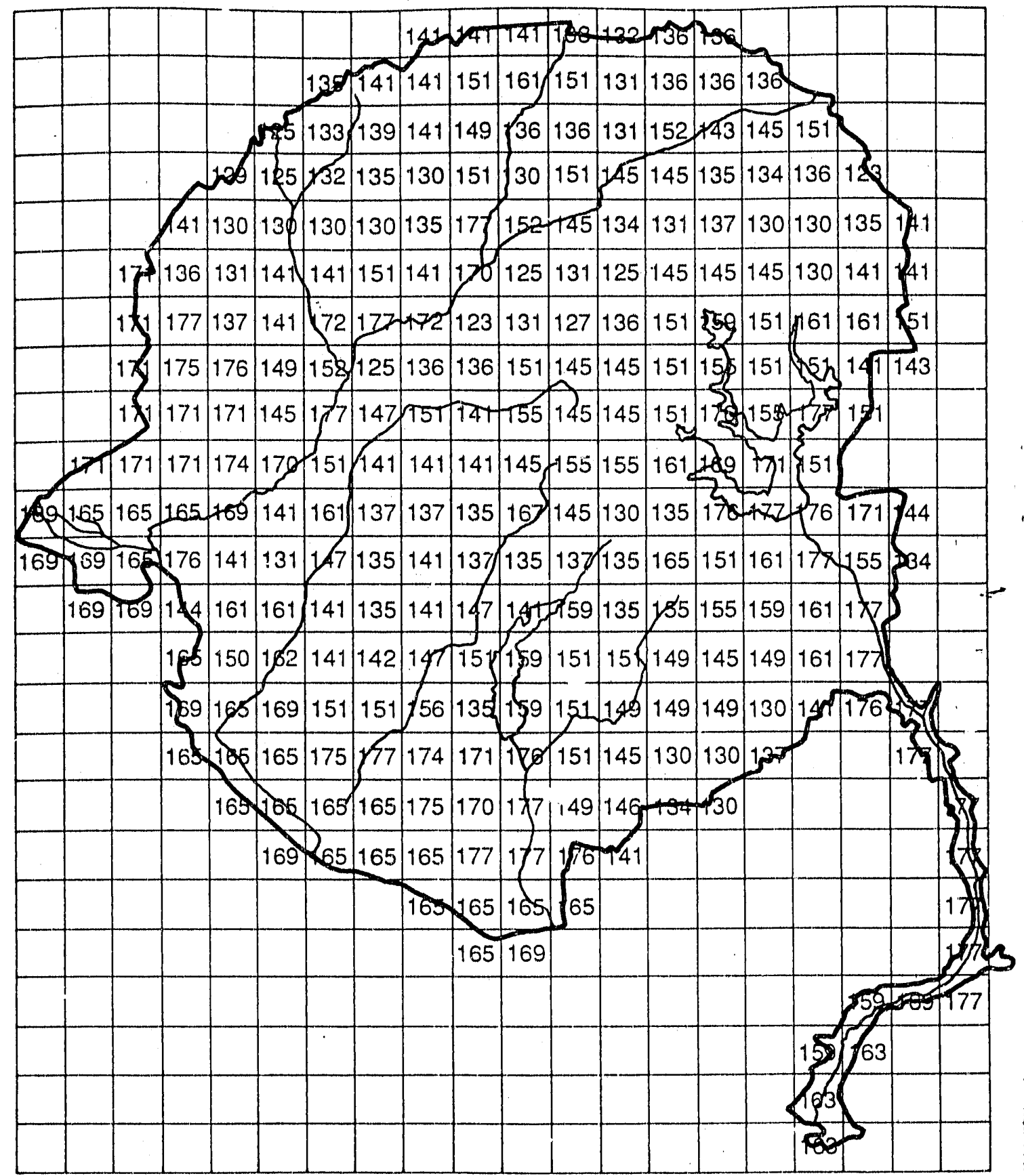

FIGURE 6. Overall DRAsTIC Indices for Each Cell 


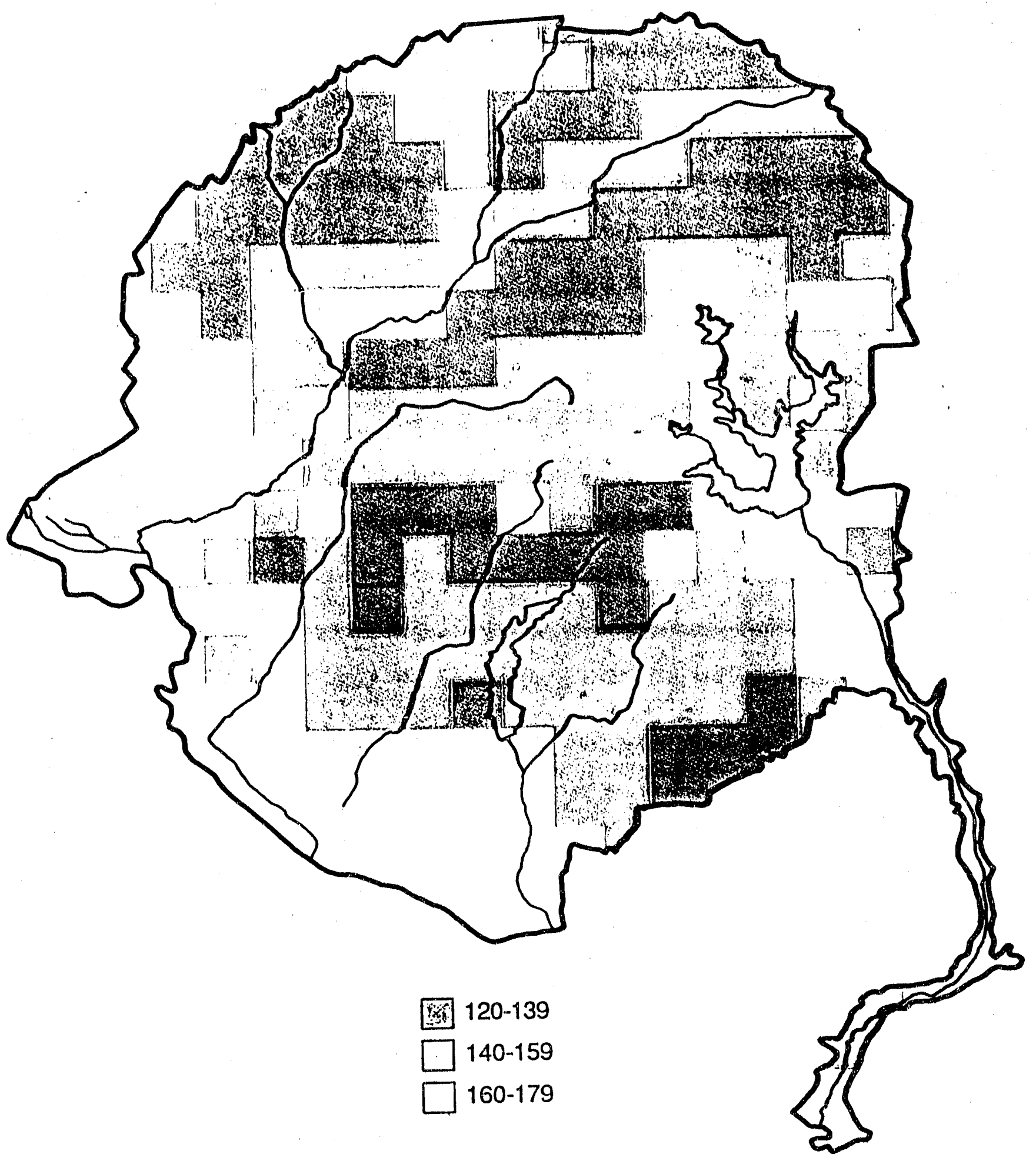

FIGURE 7. Color-coded DRASTIC Index Map 
in the less vulnerable range. It also shows that $F, H$, and $M$ Areas lie in less vulnerable locations. Based upon this cursory DRASTIC analysis, they are well-sited. The other industrial areas appear less well-sited because they are surrounded by regions with higher DRASTIC indices. However, it is very important to note that DRASTIC does not consider distance from the plant boundary, potential seismic activity or preferential flow paths underlying or within water table aquifers, any of which may be more important than all the DRASTIC factors combined.

According to DRASTIC, less vulnerable sites not yet developed are on the werge of land between Upper Three Runs and Tinker creeks in the north and at two isolated spots in the southeast. Nevertheless, because of Iimitations mentioned above, these sites may be less desirable for other reasons that have no effect upon DRASTIC's results. 
DRASTIC in many respects oversimplifies groundwater pollution potential at the SRS. But it does offer some important insights. Primarily, it provides some evidence that the original siting decisions for SRS facilities were sound ones so far as groundwater protection goes, and that the reference site for the NPR is well-chosen.

On the other hand, this was a cursory application of DRASTIC. It was a rough application of a rough approximation. Because the cells were almost $3 \mathrm{~km}^{2}$, there was enough room to have influential information slip through the grid, and not be counted. However, this could be avoided by making the grid tighter, perhaps by reducing the cell length from 1700 to $30 \mathrm{~m}$, as in the example noted previously (Beard and Rowland 1988). Also, the 4 factors given sitewide values--net recharge, aquifer media, impact of the vadose zone, and hydraulic conductivity--should be analyzed more carefully to identify variations that surely exist, and that could be pinpointed if the cells were smaller.

In that case, applying DRASTIC by hand would be impractical; a GIS would be essential. Building initial data bases for a GIS is difficult, but that work is progressing at the SRS (and at other agencies), and will most likely include at least some of the data needed to produce a DRASTIC inclex map. Topography, soil types, and potentiometric surfaces will be some of the first things put into digital form. In fact, for many places in the U.S., the U.S. Geological Survey already has Digital Elevation 
Models (DEMs) that are elevations-above-sen-level, in meters, spaced at regular $30 \mathrm{~m}$ intervals on the ground, and the soil Conservation Service has digitized maps of soil types in $3.75^{\prime \prime} \times 3.75^{\prime \prime}$ latitude/longitude grid cells.

Furthermore, there is no reason not to tailor the DRASTIC method to include additional factors that are very important at the SRS, or to account for the available data, making it more useful here. Perhaps it ought to be applied to only part of the plant, where most activity takes place, or where the data is more complete.

DRASTIC has been used most often by county planning commissions, particularly in counties served by the Tennessee Valley Authority (TVA). There they use it in conjunction with geographical information systems (GIS) software (although the DRASTIC procedure is not a computer program). In the case of the example mentioned before, Beard and Rowland (1988) applied it to Madison County, Alabama, which is where two large government industrial facilities are located: the U.S. Army's Redstone Arsenal, and, NASA's Marshall Space Flight Center. If DRAS'TIC were applied similarly to the SRS, at least the results could be used to show to a skeptical or misinformed public that a widely accepted, common sense approach to siting is followed here, just as it was at another place where there are large government facilities. 
Aller, L., Bennett, T., Lehr, J., and Patty, R., 1987. DRASTIY: A standardized system for Evaluating Ground water pollution Potential Using Hydrogeological settings, EPA/600/2-87/01B, U.S.E.P.A., Ada, OK.

Beard, L. M. and Rowland, B., 1988. Madison County, Alabama DRASTIC Application, WR28-1-520-146, Tennessee Valley Authority, Norris, TN.

Christensen, E. J. and D. E. Gordon, 1983. Technical summary of Groundwater protection Program at Savannah River Plant, Volume I: Site Geohydrology, and solid and Hazardous wastes, DPST-8 I829, E. I. du Pont de Nemours and Company, Savannah River Laboratory, Aiken, SC.

Andersen, P. F., Sims, P. N., Davis, D. H., and Hughes, S. C., 1988. A Numerical Model of the Hydrogeological system Underlying the Savannah River Plant, Report to the Westinghouse Savannah River Company, Savannah River Laboratory, Environmental Sciences Section, Aiken, Sc, by GeoTrans, Inc., Herndon, Virginia. 

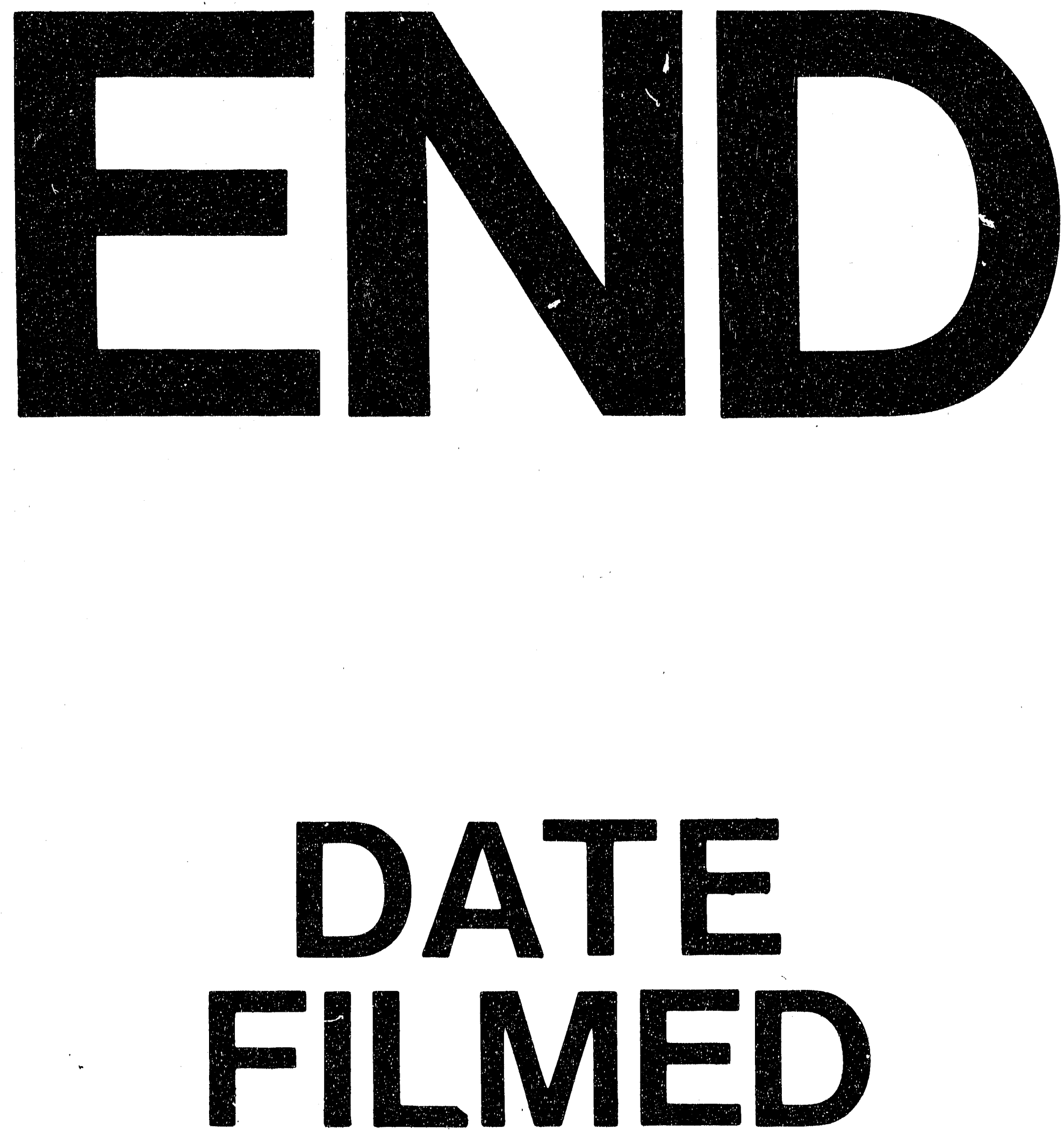

刋

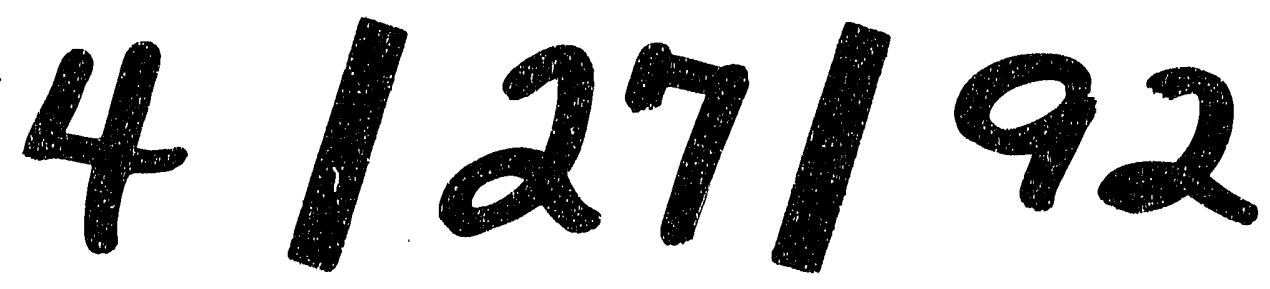


